\title{
Poetics and Politics of Borderland Dwelling: Baltis in Kargil
}

\section{Radhika Gupta}

\section{(2) OpenEdition}

\section{Journals}

\section{Electronic version}

URL: http://journals.openedition.org/samaj/3805

DOI: $10.4000 /$ samaj.3805

ISSN: $1960-6060$

\section{Publisher}

Association pour la recherche sur l'Asie du Sud (ARAS)

\section{Electronic reference}

Radhika Gupta, «Poetics and Politics of Borderland Dwelling: Baltis in Kargil », South Asia

Multidisciplinary Academic Journal [Online], 10 | 2014, Online since 25 December 2014, connection on 19 April 2019. URL : http://journals.openedition.org/samaj/3805 ; DOI : 10.4000/samaj.3805

This text was automatically generated on 19 April 2019

\section{(c) (i) $\odot$}

This work is licensed under a Creative Commons Attribution-NonCommercial-NoDerivatives 4.0 International License. 


\title{
Poetics and Politics of Borderland Dwelling: Baltis in Kargil
}

\author{
Radhika Gupta
}

'What the map cuts up, the story cuts across'

(de Certeau 1984: 129)

1 As India awoke to its freedom at the stroke of the midnight hour in August 1947, whilst millions in Punjab and Bengal fled in caravans (kafilas) and trains to seek refuge in their new homes, the fate of many others remained unsealed for a long time after. In the far north-western region of Kashmir, people in the areas of Kargil and Baltistan were late wakers to the stirrings of the Partition. Elders in Kargil recall that the force of events struck them only when the Gilgit Scouts (a paramilitary force originally raised by the British in the Gilgit Agency), which had rebelled against the decision of the Hindu Dogra Maharaja of Kashmir to accede to India, reached Ladakh in October 1947. According to local historians in Kargil it was only when the Indian army, dispatched from the plains, repulsed the Scouts out of Ladakh in May 1948 that people in this region realized they were henceforth a part of India. Ladakh wazarat (province) was sundered, with Kargil and Leh incorporated into the Indian state of Jammu and Kashmir and Baltistan into the Northern areas of Pakistan or the present day Pakistan administered region of GilgitBaltistan. The destiny of people in Ladakh (Leh and Kargil) became entwined with that of disputed Kashmir, to which India and Pakistan lay claim even today. However, unlike some separatist movements in the Kashmir Valley that call for azadi (freedom) from India, people in Ladakh-both Muslims and Buddhists-have remained resolutely pro-India and strive to make their distinct political voice heard in the national mainstream. The reiteration of patriotic sentiments in a contentious 'border' location is also an important claim-making device used to garner political and developmental support from the central government in India. Yet hidden beneath this overt discourse is the more delicate balancing act between a politics of belonging to India and a poetics of longing for a space unfettered by geo-political barriers erected by the Partition, which is expressed through the circulation of cultural forms sustained by shared linguistic and religious histories. It is to this story that this article turns. ${ }^{1}$ 


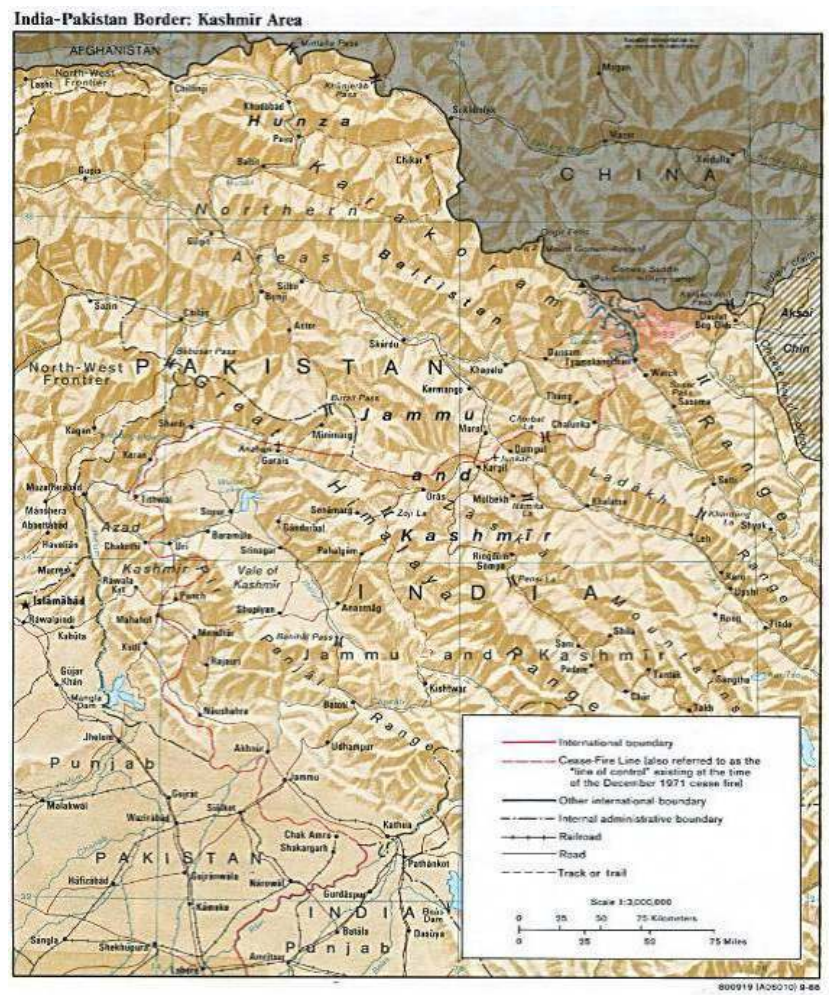

Perry-Casteñada Library Map Collection, University of Texas, Austin (http://www.lib.utexas.edu/maps/ kashmir.html).

With the Partition many fled to the 'other' side from the erstwhile Ladakh wazarat too. But scores of people also found themselves involuntarily left on one side or the other of the 'line of control' (LoC), the 'cross-border dwellers' (Rahman \& van Schendel 2003), a category of people whose postcolonial predicaments remain relatively understudied in comparison with Partition refugees. Among them were the Baltis, descendants of traders from Baltistan, who settled in Kargil and Leh for business, and others who had migrated in search of labour work to other parts of North India. They suddenly found themselves on the 'wrong' side of the border, separated from their close kin and ancestral lands.

Unlike other borderlands in South Asia, particularly those that India shares with Nepal and Bangladesh, which are often porous and see both licit and illicit flows of people and goods across them, ${ }^{2}$ heavy policing, especially after the 1999 conflict with Pakistan, coupled with the natural barrier of the mountainous terrain permitted few border crossings between Kargil and Baltistan. Caught in the crossfire of political tension between India and Pakistan over Kashmir, legal travel to meet their kin across the border was impossible for Kargilis due to the difficulties in obtaining visas until the 1980s. Illegal travel was far too dangerous. Thus, areas such as Baltistan and Gilgit, through their very unattainability, acquired heightened emotive power in the Kargili imagination. Despite the impermeability of the border, people in Kargil, especially those who originated from the regions of Baltistan, Gilgit and Chilas that now lie in Pakistan, continued to maintain strong emotional and cultural links across it. From the late 1980s a few individuals from the Balti community in Kargil managed to obtain permission to travel to Baltistan to meet their kin. Narrations of these travels in Baltistan and objects carried back imaginatively recreate the borderland for those who have never been to the 'other' side. These stories acquire a life of their own through renditions by those who have neither experienced the 
Partition nor travelled to Baltistan and Gilgit. These renditions echo what Kabir (2013: 26) terms 'post-amnesias' whereby later generations explore places lost to them through 'a combination of psychological and political imperatives'. They question, blur and transgress boundaries (Jackson 2002: 25). Imbued with joy, irony, sadness and humor, the stories are 'structural in-betweens' (ibid.), provoking a re-thinking of the region along pre-Partition borders. Some of the narratives, particularly those of cultural activists, try to promote the concept of 'Greater Ladakh'. ${ }^{3}$ Though an imagined region that harks back to the territories encompassed by the Ladakh wazarat, it could not only be read as lending credence to the concept of South Asia but even going beyond it. It foregrounds the cultural coherence of the region that rests on trans-Himalayan contiguities of landscape, language, dietary habits, material culture and ethnicity, transcending the national cultural identities that India and Pakistan tried to create through a process of 'mirrorimaging and misrecognition' resting on the secular-Islamic dichotomy (Borneman 1992: 4). However, the vast majority, including cross-border dwellers, on both sides of the 'LoC', constantly calibrate this regional imagination with iterations of national belonging as integral to their political selves. Heightened patriotism in Kargil is couched in the language of Indian secularism. People in Kargil praise India's secular ideology despite the awareness and experience of its obvious failures. This endorsement is especially provoked by sectarian violence across the border against Shi'as in GilgitBaltistan. The majority of Kargilis, including the Baltis, are Twelver Shi'a. I repeatedly heard that despite living in an Islamic state, Shi'as in the Northern Areas of Pakistan are subject to oppression by the majority Sunnis, while they themselves can live and practice their religion relatively peacefully in India.

The Baltis in Kargil claim a strong sense of belonging to India while simultaneously longing for Baltistan. However, they have no desire to return to their ancestral homes in Baltistan. Their sense of rootedness in India is evident in statements such as 'we would be happy to die here', typifying the migrant or diasporic experience wherein dying in a place as opposed to being born there marks a sense of belonging (Ho 2006). On a more abstract level, a sense of belonging emerges out of kinship, nation-ness and citizenship (Borneman 1992). Baltis have struggled and got political membership in India but their kinship networks have been fragmented or amputated. They long to reunite families and meet their kin and friends on the other side. However, the difficulty of obtaining visas, the closure of overland travel routes and surveillance of those who do manage to travel by both the Indian and Pakistani state convert kinship into a political category. The deafness of the state to this creates a tension between the 'geobody' of the nation-state and the affective body of the citizen. ${ }^{4}$ Seemingly contradictory emotions of belonging and longing lend insight into the poetics and politics of borderland dwelling. Borderlands are not merely geographic or political but also 'existential situations of being betwixt and between' (Jackson 2008: 377). This is brought into sharp relief particularly through the stories of individuals, through biographical narrative.

Following a brief history of Balti settlement in Kargil, the first part of the article will discuss the poetics of longing for Baltistan. It is not merely literal poetry, a major form of cultural production exchanged across the border, which the 'poetics of longing' refers to. It is a phrase that expresses the poignancy of longing for the other side through evocations of landscapes and shared cultural histories that predate postcolonial geopolitical barriers in South Asia. This will be followed by a biography of a Balti intellectual in Kargil who has visited Baltistan. His personal narrative is a critical 
reflection on the social and cultural milieu on either side of the border, which I suggest could be read as a very subtle critique of politico-cultural ideologies of nation-making. The last part of the paper will discuss the politics of belonging to India. In the absence of a desire to return to Baltistan in any permanent way, the use of the word 'exile' by some Balti activists in Kargil is merely a poetic trope. It is the accrual of citizenship rights in India that underlines their political and cultural activism.

\section{Balti settlement in Kargil}

Balti is a generic term that is routinely used especially by the Buddhists in Ladakh to refer to all Shi'a Muslims in the region (Grist 1998). However, the Baltis are a distinct community whose ancestors migrated from Baltistan to Kargil and Leh before the Partition. Most Baltis came to Kargil as traders and are still referred to as hatti-pa (shop keepers). Some are also descendants of preachers who came from Baltistan. Shi'i Islam came to Kargil via Baltistan through the proselytization of preachers who travelled overland from Khorasan in the $17^{\text {th }}$ century. In fact, most of the historically renowned religious teachers ('ulama) in the region were Balti. Legendary among them is Shaykh Ali of Brolmo, under whom some of the most learned of the older generation of clerics in Kargil studied. His shrine (astana) in Brolmo village is visible from a rocky perch in the village of Hundarman, which was brought into Indian territory during the 1971 war with Pakistan. The shrine is prominent in the regional sacred geography of Shi'a Muslims in Baltistan and Ladakh, and residents of Hundarman relate how people across the 'border' still come to light incense and candles on Thursday evenings and Friday (Jumma), making the shrine a symbol of emotional attachment for the other side.

Three villages in Kargil district-Hardas, Lato, and Karkichu-situated on the left bank of the Drass River, a couple of miles from the main Kargil town, are predominantly Balti. These villages came under the estate (jagir) of the Raja of Kharmang, a valley in the Skardu tahsil. Baltistan was divided into the tahsils of Skardu and Kargil in 1901; Kharmang was placed administratively under the Kargil tahsil due its geographical proximity to Kargil. According to a Balti elder, the Raja brought people from Hamzigund and Singkarmo and settled them in what is present day Hardas, famous for superior quality helmund apricots. These villages provided a halting point for the Raja during his travels. In Kargil town itself, there are about five thousand Baltis, many from Kharmang, mostly living in a neighborhood called Balti Bazaar, one of the oldest bazaars in Kargil district. A well-known and much respected intellectual and poet, an ardent activist for the preservation of Balti culture, Sadiq Ali Sadiq, proudly told me in 2008 that his was the only family in Balti bazaar which remained 'pure Balti' as his children had married into families who were also descendants of people from his hometown Kharmang. There is a preference among elders that the young marry within the community. Thus, matches are even sought among Balti communities outside Kargil. A significant Balti settlement can be found in Khalsi Gate near Dehradun in Uttaranchal. They too are cross-border dwellers, descendants of Balti labourers in Uttar Pradesh and Himachal who got stuck on the Indian side after Partition. Kargil bazaar has several 'Balti dhabas' (cheap restaurants) run by Baltis from Dehradun who migrate seasonally in the summer months in search of a livelihood.

8 A part of Kharul, the summer capital of the erstwhile king of Kharmang, lies in presentday Kargil, en route to Hundarman village. Two Balti interlocutors pointed this out to me 
with much excitement when we visited Hundarman. I was told that we were now on the Kargil-Skardu road. They also mentioned that at certain places the road had even been widened in anticipation of it being opened. Yet the long-standing demands and pleas for opening the road remain unmet. A wood and steel bridge reconstructed from an old rope bridge by the Indian army in 2000 leads across the river to Hundarman. No vehicles are allowed beyond a certain point, which is guarded by an army picket. A stretch of the road before this point was within Pakistan till 1971. As we climbed up the steep path to the village, it appeared like a patch of dense green hanging over the river. When we crossed over to the other side and walked parallel to the river for a bit, one of my Balti respondents said emotionally, 'Sometimes I feel like jumping into the river and flowing away into Pakistan with it'. His statement was a reference to the lament of the Balti community in particular, but also more widely among people in Kargil, of the refusal by the Indian and Pakistani states to re-open the Kargil-Skardu road. If the road were to open, Baltis going to meet their kin would not have to travel to Skardu via Delhi to Lahore through the Wagah border in Punjab or by air covering over 4,000 kilometers when Skardu is a mere day's journey by the direct overland route from Kargil.

\section{The Kargil-Skardu road}

9 The road to Skardu from Kargil stands at the symbolic intersection of the poetics of longing and politics of belonging. For the Balti community the demand for opening the road is particularly emotional for it would facilitate travel to meet relatives more easily. However, they have not been the only ones campaigning for the road to be opened. It has also become a symbol of the sense of belonging afforded by the Indian state to people in Kargil as a whole in the context of regional politics. Kargilis argue that they proved their patriotic credentials during the 1999 Kargil war by not only alerting the Indian army of Pakistani intrusion, but also aiding soldiers on the high mountain terrain. Without local support, they argue, the Indian army, which later acknowledged this, would never have been able to win the war. Despite this, the Indian government has not opened the KargilSkardu road. A Balti interlocutor mentioned that a friend of his in Skardu had (in 2009) told him that 70 kilometers of a stretch of this road on the Pakistan side had already been macadamized. 'This means', he conjectured, 'that it is India which is not opening the road, as opposed to the propaganda that the Pakistan government does not want it to open it'. The fact that phone calls cannot be made from the Indian side to Pakistan from Jammu and Kashmir but not the other way around and that many people from Kargil have been able to obtain visas to travel to Skardu, and not the other way round, might lend support to his argument. He rhetorically proclaimed, 'This means that the Indian government does not treat us as their own'. He pointed to the disparity in the government opening the Srinagar-Muzaffarabad road even though the people of the Kashmir Valley raise anti-national slogans, while the Kargil-skardu road had remained closed despite Kargilis being patriotic citizens. He added that the Buddhists in Leh do not want the Kargil-Skardu road to be opened for communal reasons, fearing they will be outnumbered by Muslims. He lamented that opening the Kargil-skardu road has nothing to do with religion; it is for purely sentimental reasons, so that family members separated from each other from the time of Partition may be able to meet. 'Where does religion come into this?' he asked. One Balti activist in his anger and disappointment said that in part the people of Kargil are to blame, for they do not raise protest slogans. He mentioned 
that in Baltistan an organization called the 'Baltistan National Movement', which has been advocating a return to 'Greater Ladakh' (Leh, Kargil and Baltistan), organized a protest march, but that the Kargilis are too scared. He added, 'The Baltistan National Movement is so active that it even has a logo and a flag for Greater Ladakh'.

Despite their nationalist sentiments and overt endorsements of Indian secularism, the ambivalent relationship between the state and borderland dwellers becomes clear in the confusion and conjectures expressed in conversations on the Kargil-skardu road. When a person asks, 'Where does religion come into this?', it reflects the biases of Indian secularism. The sentiments surrounding the road reiterate the fracture between the geobody of the nation and the affective body of those who live on this contentious borderland. Furthermore, the long-standing desire for the Kargil-Skardu road to be opened among Baltis in Kargil often leads to a partial representation of the social and political realities in Baltistan. Thus, it is cultural movements in Baltistan lobbying for 'Greater Ladakh' that are talked about, rather than the more complicated nationalist sentiments and relationship with the Pakistani state that may be found among people in Baltistan.

11 The Baltis in Kargil are so close to Kharmang and Skardu and yet so far. I was struck in my conversations with them by the extent to which the landscape of Baltistan and Gilgit looms large in their imagination. Even people who have never had the opportunity to travel to Baltistan speak of the plains of Deosai, Rondu Valley, the forts at Shigar and Khaplu, the Sadpara Lake and the Maqpon Polo Ground in Skardu. During my visit to Hundarman three Baltis had a long discussion on places mentioned in Tarikh-e-Baltistan, ${ }^{5}$ one of the few histories of the region, saying, for instance, that forests existed in three places in Baltistan-Manthoka, Memush and Shing. Even places farther away in Gilgit such as Braldu and Astor figured in their mental mappings.

The closure of the Kargil-Skardu road has meant the closure of a pathway. The issue is not merely that it takes a longer time to get to Baltistan. Rather the cutting off of pathways, especially in the case of travel by air, leads to a flattening of the landscape and the experience of it. In his critique of the concept of space as being too abstract, Tim Ingold argues that life is ultimately lived and anchored in places. It is the 'particularity of place' which is central to sustaining a moral community defined by 'networks of personal, genealogical, familial, and status relationships', in contradistinction to the notion of territory which defines the geobody of a nation (Gilmartin 1998: 1083-84). Further, places are 'delineated by movement, not by the outer limits to movement' (Ingold 2011: 149). The closure of pathways converts wayfaring into transport. One could argue then that in having to take a circuitous route from Kargil to Baltistan, not only is territory divorced from the sense of place; something of the magic and immediacy of the landscape is also lost. However, in an ironic twist to Ingold's argument on the usefulness of the concept of space, memories of the landscape are nurtured through virtual spaces. Young Baltis today enjoy the landscape through regular exchange of photographs, old and new, via the Internet through dedicated pages on Facebook and smartphone applications. ${ }^{6}$ They also connect with relatives and friends through online chatting. Yet, this can never replace the joy of meeting in person.

With the closure of pathways and difficulties in obtaining visas Baltis sometimes look for their kin in third places such as the Hajj. Recognition of individuals still continues according to the traditional system in which families were classified into larger units defined by genealogy and reciprocity with the suffix $p a$ added to the name. In Balti 
bazaar, for instance, there are four such families-Ghulam Beg-pa, rGyalu-pa, Mekhdanpa and Hashim-pa. When people go on the Hajj they search for long-lost relatives from Pakistan by asking the name of the $p a$.

\section{The pain of separation}

14 In 2005 the International Association of Ladakh Studies held its biennial conference in Kargil. Two people from Baltistan travelled to Kargil for the first time since the Partition to participate in the conference. One of them was Ghulam Hasan Hasni, ${ }^{7}$ a poet much loved by people on both sides of the border. People in Kargil received him with adulation. The Baltis in particular were moved to the point of tears. Long sessions of poetry and laughter followed, running late into the summer nights. To convey the pain of separation from family and friends, a Balti writer, Master Sadiq Hardasi, ${ }^{8}$ related a story to me in connection with Hasni's momentous visit to Kargil.

Hasni did not tell many people he was traveling to India fearing that he would lose face if he did not get a visa. But eventually he did. On his return to Baltistan, a young man called Ashraf on hearing that Hasni had been to Kargil got very upset. Hasni learned that Ashraf's father's sister lived in Hanu village in Kargil. His father had got stuck in Pakistan when he crossed over Hanu-la [pass] and was never able to meet his sister again. Ashraf was yearning for news of his phupi (aunt). Some letters had been exchanged many years ago, but they had lost track of her for a long time now. When Hasni learnt this he put Ashraf in touch with Master Sadiq on the internet. The two became friends and chatted online. ${ }^{9}$ Ashraf requested Master Sadiq to try and track down his aunt in Hanu. Through an acquaintance of his from Hanu, Master Sadiq made enquiries and learnt that Ashraf's aunt was still alive, albeit not in good shape. She had lost one of her daughters some years ago. Then Master Sadiq himself went to Hanu and took pictures of the aunt and her family, which he sent to Ashraf. This made Ashraf extremely happy. Then one year Ashraf's aunt passed away. When Ashraf heard the news he was sad, but he said he would not cry and not allow his father to cry either as he was so thankful that at least they had been able to reconnect with his aunt and had news of her passing away. He told Master Sadiq that he would organize a fatiha in his home in Skardu for his aunt. After this Ashraf stopped chatting with Master Sadiq.

16 According to Master Sadiq he receives 'offline' messages from him once in a while but knows that Ashraf will never chat with him again. He told me that he understands whythis is because Ashraf's last link with Kargil, his aunt, is no more; 'Such is the pain of separation and loss among those of the Balti community, who still have relatives across the border'.

There are numerous stories of families being broken up between the two sides of the border. Hajji Ali had travelled to India to trade salt leaving behind a pregnant wife. He got stuck in India when the Partition happened and the border closed in 1947. His wife had a son, but he had to send her a divorce, not being able to return to Skardu. Ghulam Hussain and his siblings got separated from their parents when Hundarman suddenly found itself part of India. His father was from Hundarman but was running a shop in Skardu; the children were studying in the primary school in Hundarman. Ghulam Hussain was able to visit Baltistan to meet his mother, who was still alive, in 2008. However, most Baltis have not been fortunate enough to be able to travel to Baltistan. Never able to return, they express a deep sense of loss for their lands, homes, relatives and friends. Take the case of 
Api Fatima, one of the last of the generation who experienced the Partition in 1947-1948. She was 73 years old when I met her in 2008 and passed away a couple of years later. From Gandus village in the Kharmang Valley, she came to Kargil at the age of 12 on getting married to a trader. She was never able to visit her natal family. Our meeting started off on a jovial note, with Api reminiscing about the way women in Kargil dressed in the older days. She pulled her shawl over her forehead to demonstrate how they observed proper hijab compared to the young girls today. She talked of the apple orchards in her village in Baltistan. As we were talking, her daughter cautioned me to not press her for too many memories for she was bound to get upset. A few years ago her elder sister in Pakistan sent her a video of her family, which made Api cry. Ever since, Api began collecting anything nice that she found in the hope of giving it to her sister one day (Gupta 2013).

Just as Api Fatima was yearning to give her sister many precious things from India, gifts carried back from Baltistan by those who manage to travel hold a heightened emotive value. A lady from Balti Bazaar had dressed especially for an outing to Hardas during the apricot season one summer. She pointed to her salwar-kameez to say it was made out of material her husband had brought back from Baltistan. On another occasion, her husband offered me a bowl of dried apricots saying I must try them as they were from Baltistan, where the best helmund apricots are grown. Yet another day, a different respondent even brought a collection of catalogues from a furniture shop in Skardu to show me their experiments with local material. Hasni himself gave some of us at the IALS conference in 2005 small pieces of jade as good luck charms, which many Baltis in Kargil told me were very precious. It is as if lost connections inhere in these objects.

Classical anthropological theory on the basic rules of exchange systems has taught us that societies exchange words, women and goods (Borneman 1992: 10). Besides facilitating the meeting of kin, demands for the opening of the Kargil-skardu road are also made for facilitating trade, for the freer exchange of goods. Until the road opens people on both sides of the border will continue to attach added value to goods from the other side. For now they must remain content with the exchange of words. Indeed, for Baltis it is largely words that can be exchanged unfettered across the border. In the absence of travel, poetry and music bring both sides together.

It is not just with the elderly like Api Fatima, who has childhood memories, that Baltistan has an emotional resonance. A younger generation of Baltis holds equal enthusiasm for visiting and maintaining ties with their ancestral lands. However, their desire for Baltistan is underlined by something more than wanting to locate and meet family there. It is driven by a 'thirst for our culture', as a young Balti activist put it.

\section{Balti adab}

The Baltis in Kargil make claims of being the upholders of the classical culture of the region. There is no match for Balti adab (refinement, etiquette), they argue, for Balti is the 'original', 'pure' (asli) language of the region. ${ }^{10}$ Unlike the lingua franca, Purigi, which too is a dialect of classical Tibetan, Balti, they claim, has not been contaminated by Urdu words. ${ }^{11}$ Purigi activists contest this within a growing politicization of identity along ethnic lines in the region. ${ }^{12}$ They argue that Purigi is the 'original language of the region'. As Master Hussain of Silmo village proclaimed, 'I challenge the Baltis to show me even one poem without a single word of Urdu, Persian or Arabic in it'. 

from religious poetry (qasida, nauha, marsiya) to Persianate forms (ghazal, goshwara, diwan and bahr-e-taweel). ${ }^{13}$ The origin of Balti majlis music in Baltistan is an important source of legitimacy, authenticating the small Balti community's claim to being the upholders of high culture or adab as compared to Purigi in Kargil. Poets like Bashir Wafa and Septe Kalim, who have visited Baltistan, returned with stories extolling the literary culture of Baltistan. They reminisced about the special mushairas (poetry sessions) that were organized in their honor, lamenting the relative 'shallowness' of Kargil's literary scene ${ }^{14}$. Recordings of these mushairas are watched with much eagerness by Baltis and others in Kargil, as are photograph albums of their visits. has produced music CDs of classical poetry set to pop music. These CDs are also sent to Baltistan via pilgrims and relatives (Magnusson 2011). Although competing with Bollywood music these albums are fairly popular in Kargil; I often heard them playing in local buses and shared taxis. Listening to old Balti qasidas and ghazals on Radio Skardu was a popular source of entertainment for the older generation and women who do not easily understand Urdu, until the enhanced 200 Kilo Watt (in 2005) of All India Radio in Kargil diminished the clarity of Radio Skardu. The sharing of poetry is an important example of the circulation of cultural forms across the border despite limited mobility. The majority of the poems are on romantic and everyday themes, not directly or necessarily expressing longing for the other side. Rather it is through the persistence of a shared cultural space that cuts across the border that the emotion and affect denied by the state find succor. The effort put in to maintain this cultural space speaks of the poetics of longing rather than the actual poetry itself.

Balti intellectuals in Kargil proudly maintain small personal libraries in which books brought back from Baltistan hold pride of place. A Balti from Hardas told me he brought back 80 kilos of books in 2012. Books from Baltistan are also often received by post and through relatives going on pilgrimage. These poets and writers sing high praises not only of contemporary poets like Hasan Hasni, but also memorialize old Balti writers like Ba Abbas, Mansoor and Mohaib, whose names cropped up frequently in our conversations. Despite the growing popularity of Urdu nauhas and marsiyas from Pakistan, people prefer to listen to and render older Balti poetry on the most solemn days of Muharram. Akhon Asgar Ali Basharat, a poet from Karkichu village, collected and compiled some of this older poetry, especially religious poetry, preserving it for posterity. The vibrant cultural exchange between poets, musicians, and writers in Kargil and Baltistan brings to view the 'unofficial history' of the Partition: 'the collective voice which persists-in the sharing of language, in poetry, and music and performance' (Sen 1997

According to Nosheen Ali (2012), poetry in Gilgit-Baltistan contests the religious authoritarianism of the Pakistani state. While this is not the case in Kargil, the experience of the cultural exchange has been a site for reflection on the social milieu on either side of the LoC for some Balti intellectuals in Kargil. It contributes to the formation of what might be termed cosmopolitan subjectivities. I explore this through the biography of a Balti intellectual. Despite being a somewhat idiosyncratic character he offers a critique of the wider context in which cultural conversations across the LoC are embedded.

South Asia Multidisciplinary Academic Journal, 10 | 2014 


\section{A biography: transcending dichotomies?}

Bashir Wafa is a well-known cultural activist and poet in his mid-forties from Balti Bazaar in Kargil town. The first time I met him, he was wrapped in a hand-woven traditional woolen shawl, which he usually dons for visitors to signify his Balti identity. Wafa had the opportunity to visit Baltistan in 2007 and reminiscences from his three-month stay in Skardu came up in our first and subsequent conversations. One afternoon he pulled out photograph albums of his visit. Pointing to famous local poets in Baltistan at various mushairas held in his honor in Skardu, he wistfully recalled going to as many as fortyseven mahfils, many of which continued through the night. To convey the affection with which he had been received in Skardu, Wafa told me about the poem he had composed to recite at his farewell. Clearly reflecting his own emotions, the verse anticipated the darkness that would descend upon the mahfil in Skardu when he left and urged people to light a candle to dispel it. But the darkness lingered, a friend in Skardu called to tell him, when he was back in Kargil. Such was the emotional intensity of his visit.

Married to a Purigi woman, Wafa considered himself lucky to have found a wife who understood his liberal outlook and passion for poetry, reading, and writing. Wafa's intellectual aspirations and interests were conveyed by his visiting card: 'Bashir Wafa (Balti): Poet, Drama Artist, Sports Commentator'. One day, pulling his shawl tightly across his shoulders as the evening chill seeped into the room, enclosed by glass windows looking onto the Suru River, Bashir Wafa slipped into a momentary reverie: 'When the moon rises from behind the mountain across the river, it casts its beautiful light into this room and gives me inspiration for my poetry'. Then laughing, he added that in order to write he would also need to be continuously supplied with tea and cigarettes. One afternoon, he pointed to his modest bookshelf, proudly telling me that he had sourced some titles all the way from Pakistan. Nostalgically, he recalled visiting the World Book Fair in Delhi. He enjoyed reading Premchand, Manto, Ismat Chugtai, and even James Hadley Chase. Both Manto and Chugtai are considered the most progressive writers of the Partition era. They boldly wrote against the dominant grain of social mores.

Conversations with Wafa were always freewheeling, seamlessly shifting between past and present, wry humor and serious reflection. He would often describe his days as a laborer in Shimla (Himachal Pradesh) and the joy of meeting people from other parts of India. He reminisced about evenings spent at the 'Shimla bar' with Hindu friends, where he satisfied himself with cashew nuts while they drank alcohol. Religious differences did not stand in the way of friendships and the years in Shimla played a crucial role in exposing Wafa to different ways of living and thinking. As if to convey his cosmopolitanism, he proudly told me that barring his abstinence from alcohol and consumption of non-halal meat, no one in Delhi would be able to tell he is an outsider: 'I know how to behave in every context, be it a cabaret, a five-star hotel, or a railway station'.

The strength of Wafa's intellect and its eclecticism, conveyed by him as possessing an 'open- minded' and 'secular' outlook, was perhaps most poignantly illustrated by his 'Darling' story. Wafa communicated fairly regularly with friends in Baltistan via the Internet. As he related it to me:

One day, he received a chat request from a woman in Khaplu who called herself 'jannat $k i$ shahzadi' (princess of paradise). Two of Wafa's friends in Kargil had chatted with her previously. After checking on the woman's credentials through his niece in Baltistan, 
Wafa started chatting with her. At the onset of their communication, he warned the woman of his quirky nature, telling her that some of his ideas may seem outrageous to her, shaped as they were by a context, which is not as strictly Islamic as Baltistan, since he lived in a 'secular country'. After a rapport had developed between them, Wafa decided to 'test the woman' and jokingly addressed her as 'Darling'. He used the phrase purposely as a tool to judge her 'way of thinking'. There was no reaction from the princess. However, a few days later a friend of Wafa, who had also chatted with her, came and asked him with apparent innocence the meaning of the word 'Darling'. Wafa realized that news of his chat had spread. He explained to his friend that 'Darling' was a general term for expressing endearment; it could be used by parents for their children. His friend insisted that it was a romantic term. Wafa realized that the woman failed his test to see how 'broad-minded' she was and his reputation was at stake. To express his anguish at being misunderstood, that he had only used the term in jest, Wafa wrote a long letter to a well-known intellectual in Baltistan.

31 A photocopy of the letter was carefully preserved in a file along with his other writings, which he hopes to compile into a book someday. Interspersed with Urdu verse, the letter dwelt upon Wafa's 'inner life' and how he came to be the person that he is. While provoked by the 'Darling' episode, it went much beyond and could be read, I suggest, as a social commentary. Lamenting to his friend that people today have little time for laughter and must be warned to laugh before telling a joke, he indirectly spoke to the woman through this letter:

'Thinking of you as an 'open-minded woman', in my own andaz (manner/style), I put myself in the role of Saadat Hasan Manto and you in that of Ismat Chugtai'. He wrote that little did he realize that she too had a 'rural' mentality of 'close-mindedness' (bichdi hui, tang nazar), and was not able to take a joke in the right spirit, that of adab-i Baltistan. The spirit of what Wafa was trying to say was perhaps best expressed in a piece that Manto (2000) wrote on Ismat, offering tender insight into their friendship. He wrote of her reaction to a story of his:

She was unusually enthusiastic in her appreciation of 'Neelam'. 'Truly what is this rubbish about adopting a woman as a sister... you are absolutely right. It's an insult to a woman to be called a sister'. And I was left thinking-she calls me Manto bhai and I call her Ismat Behen-God alone knows why.

Perhaps Wafa was looking for a companion who shared his thinking, akin to the companionship that Manto and Chugtai shared in their writing. It is true that this is only Wafa's side of the story and we can glean little from it of the woman's thoughts on the conversations with him. Perhaps the woman did not have the same kind of exposure that Wafa had given that the literary culture of Baltistan is largely male-dominated as is that of Kargil. It was Wafa's own expectations and imagination of a more expansive and open adab-i-Baltistan that were disappointed.

He spoke of adab not just as etiquette and refinement in the distinction he made between rural and urban women but also as an expression of a wider worldview that transcends any form of narrow thinking. Just as Wafa's inspirations, Manto and Chugtai, broke the writing conventions of their times to reveal the underside of society, his own thinking was a critical commentary on society in both Kargil and Skardu. He derided puritanical versions of religiosity and parochialism of any kind. Wafa had always been critical of excessive religious injunctions, criticizing, for instance clerics' discouragement of music and dance, as stifling creative expression in society. Wafa wrote in his letter that despite 
the changing times, he adhered to his principles, which were above all that of insaniyat (humaneness), shaped as much by Islam as his service in the National Scouts where he had mingled with people from different religions and walks of life. Implicit in such statements are efforts that people, particularly Muslims, living on the India-Pakistan border, make to balance the values derived from Islam with the nationalist ideology of secularism in India.

In the many conversations that I had with him, Wafa would return to his frustration with being unable to find people with whom he could have meaningful, reflective conversations in Kargil. His sentiments resonated with the search for an inner life and reflective relationships that Magnus Marsden has written about directly across the border in Gilgit and Baltistan (Marsden 2005).

Wafa's cosmopolitanism derived not from fashionable global ideas or world travel, but from a rootedness in the poetics and politics of his locality that transcended the constraints imposed by political borders. His outlook was also a reflection of a longstanding tradition of Muslim literary humanism in South and Central Asia (Ali 2014). One day I noticed the TV cabinet in his home. On one of the door knobs of the cupboards on either side of the television hung a traditional Balti cap and on the other side a Bharat Scouts (national scouting and guiding association of India) cap. Placed on the shelf inbetween was a photograph of Hasan Hasni. This unconscious placement of personal objects of sentimental value effectively portrayed in a single visual image the discursive resources drawn from both sides of the border that have shaped Wafa's outlook.

The finesse of Bashir Wafa's thinking derived from the way the perceptions and experience of one context were refracted through those of another. Wafa's biography rendered through his own narrations conveys how typifications of identity in categorical religious or secular terms imposed by post-colonial states in South Asia break down at the level of individual subjectivity. Wafa to me represents what Pandey calls the 'fragment' of society, which resists any 'drive for shallow homogenization' and challenges 'binary categories of secular/communal, national/local, progressive/reactionary' (Pandey 1992: 28- 29).

The secular/Islamic dichotomy through which India and Pakistan define themselves as mirror images of each other are not distant and abstract categories for those who live in their borderlands. They take on a particular salience for the Baltis in the context of spiraling sectarian violence against Shi'a Muslims in Pakistan. News of deaths and murders in Gilgit-Baltistan are mourned in Kargil not only because of kinship ties across the border but because of the decimation of a shared place often evoked as 'Greater Ladakh'. However, unlike nationalist movements that call for a return to 'Greater Ladakh', and oppositional cultural activism in Gilgit-Baltistan that seeks to distinguish itself from the majoritarian Islamic state of Pakistan, people in Kargil are continually engaged in a politics of belonging that seeks to cement their place in India. This is often expressed through endorsements of the official definition of India's secular ideology despite its apparent contradictions. In his nostalgic reminiscences of Parkuta Nallah in Baltistan, Ghulam Hussain from Hundarman recounted how people there had been curious about Kargil. They asked questions like whether the Indian government allows them to hold Muharram. He told them there is peace in India and anyone can pray in whatever way they want; on Ashura the army even halts its convoy for the procession to pass. To this they responded, 'Hindustan ka ain achha hai' (the rules/laws of Hindustan are good). 


\section{Politics of belonging}

like cooking gas, for instance, in comparison to the prices in India. They may praise the quality of schools and roads there but clarify that this is the work of external agencies like the Aga Khan Foundation rather than the Pakistani state. Aware of the political alienation among the Shi'a Muslims in Gilgit-Baltistan they stress that in comparison to Baltistan people in Kargil are getting rights and amenities. They cite certain privileges of Indian citizenship that they have been accorded such as 'Scheduled Tribe' and 'State Subject' status in Jammu and Kashmir. ${ }^{15}$ Baltis settled in Uttaranchal have been lobbying the Uttaranchal government for recognition of their community as a Scheduled Tribe but have been unsuccessful thus far. Some of them have come to Kargil to try and get State Subject status in Jammu and Kashmir through their kinship connections or holdings of land in the region if they are able to find the records. Their sense of rootedness in India is further reflected in a petition made to the state government for allocation of land in Kargil in lieu of their land in Baltistan. It is easy for them to provide proof of land ownership, they claim, as most of the land records are still in Kargil as Kharmang fell in Kargil tehsil before the Partition. Yet continued struggle by some to receive State Subject or Scheduled Tribe status, the search for records of land holdings and petitions for compensation for lands left behind in Baltistan attest to the 'Long history of Partition', which Vazira Zamindar (2007) has so powerfully described in her work on resettlement and 'refugees' in Delhi.

Despite this integration into mainstream governance categories, Balti activists often speak of feeling marginalized. Intellectuals like Wafa have acquired a vocabulary of exile through exposure to the wider world and interaction with scholars: 'We feel a complex here,' he stated one day, lamenting that there is an insufficient appreciation of Balti culture in Kargil. Relating how hard the Baltis have worked to keep their culture alive, he added, 'After all we cannot compel ourselves upon others, we are a minority'. This sentiment has become particularly acute with the rise of intra-regional ethnic politics especially vis-à-vis the Purig-pa. In order to promote their culture and ethnic identity, Balti activists skillfully deploy their insider-outsider status. For instance, their designation by Buddhists as 'outsiders' (those who came from Pakistan) underlines their claim that the half-hour slot for a Balti programme on All India Radio Kargil was allotted only after they convinced the authorities that it would act as a counter to Pakistani propaganda on Radio Skardu. While these acts could be seen as strategies of claimmaking, they also reflect the fragility of the sense of political belonging, which must be continually reiterated through allegiance to India. Endorsements of Indian secularism are central to this vocabulary of allegiance. 


\section{Concluding remarks} The case of the Baltis in Kargil does not subscribe to the category of either 'transmigrants' or people in exile. Even though they maintain ties with their ancestral 'homelands' through kinship, friendship and religion (Borneman 1992), they are not engaged in 'long-distance nationalism', by being involved in political struggles in Baltistan. ${ }^{16}$ Neither are they in exile given the absence of a desire to return to Baltistan in any permanent way. Nor are they refugees in the sense that they did not flee Pakistan voluntarily seeking refuge in India at the time of the Partition. The deployment of tropes of 'exile' and 'refugee' are claim-making strategies rather than structures of feeling. What then can cross-border dwellers whose subjectivity is shaped as much by a politics of belonging as a poetics of longing tell us about the relationship between borderland dwellers and the state in post-colonial South Asia?

Though writing about the very different context of postwar Germany, Borneman offers the important insight that 'it is precisely around belonging to a nation that kinship and the state come together in a single frame' (Borneman 1992: 30). In their politics of belonging Baltis certainly draw upon 'master narratives' of the state as we saw in the expression of a 'secular outlook' in Wafa's biography and praise for the law of the land. They have gained political citizenship through the recognition of their community as a Scheduled Tribe. However, their poetics of longing unsettles the construction of a single frame that brings together kinship and state. The refusal to open the Kargil-skardu road creates a wedge between the geobody of the nation-state and the affective body of the citizen. Calls for opening the road are above all a matter of emotions borne from the intense desire to be reunited with family and friends from whom they have been separated since the Partition, for the restoration of kinship ties. Yet it is arguable that the routinization of response and apathy of the state to narratives of emotion related to kinship render their sense of belonging with a feeling of incompleteness. This is expressed in the sometimes rhetorical but perhaps nonetheless meant conjecture that it is the Indian state which is more averse to the opening of the Kargil-skardu road also suggested by the relatively fewer visas granted to people from Baltistan to visit Kargil as compared to the other way round. As Borneman has written, 'Unlike law and policy texts, personal recollections rarely attempt to divide history into discrete categories of political and domestic life, into a set of objective circumstances and subjective responses' (ibid.: 38).

44 Individual narratives of real or virtual travel to Baltistan not only express a poetics of longing but also offer a subtle critique of dichotomies on which the legitimacy of India and Pakistan rest. Travel to Baltistan renews an appreciation of Indian secularism, which falters in the context of oppression of and violence against Muslims in other parts of India or has been imposed on Muslims in India since Partition as a de facto condition of belonging. These narratives critique the Islamist ideology of the nation-state in Pakistan where minority sects are subject to spiraling violence. However, they also strengthen a sense of regional identity that is shaped by a longer history of cultural and religious ties that cut across the borders of the nation-state. They bring forth a temporality that disrupts the spatiality of nation making. Though Baltis on both sides of the border will never be content with just the exchange of words, their stories will remain powerful

South Asia Multidisciplinary Academic Journal, 10 | 2014 
mediums of boundary crossings. These, I suggest, will continue to vivify the concept of South Asia, problematic as it may be in its origin and other contexts.

\section{BIBLIOGRAPHY}

Aggarwal, Ravina (2004) Beyond Lines of Control: Performing Borders in Ladakh, India, Durham: Duke University Press.

Ali, Nosheen (2012) 'Poetry, Power and Protest: Reimagining Muslim Nationhood in Northern Pakistan', Comparative Studies of South Asia, Africa and the Middle East, 32(1), pp. 13-24.

Ali, Nosheen (2014) 'Between State and Society: Poetic Engagements with Power in Northern Pakistan', paper presented at the conference convened by Michel Boivin \& Julien Levesque, Islam and Regional Cultures in Pakistan, Paris, EHESS, 6 June.

Bhan, Mona (2014) Counterinsurgency, Democracy, and the Politics of Identity in India, Abingdon \& New York: Routledge.

Borneman, John (1992) Belonging in the Two Berlins: Kin, State, Nation, Cambridge: Cambridge University Press.

Cons, Jason (2013) 'Narrating boundaries: Framing and contesting suffering, community, and belonging in enclaves along the India-Bangladesh border', Political Geography, 35, pp. 37-46.

Ghosh, Sahana (2011) 'Cross-border activities in everyday life: the Bengal borderland', Contemporary South Asia, 19(1), pp. 49-60.

Gilmartin, David (1998) 'Partition, Pakistan, and South Asian History: In Search of a Narrative', The Journal of Asian Studies, 57(4), pp. 1068-95.

Glick Schiller, Nina; Fouron, Georges Eugene (2001) Georges Woke Up Laughing: Long-Distance Nationalism and the Search for Home, Durham and London: Duke University Press.

Grist, Nicola (1998) Local Politics in the Suru Valley of Northern India, Unpublished PhD thesis, Goldsmiths College, London University.

Gupta, Radhika (2013) ‘Allegiance and Alienation: Border Dynamics in Kargil’ in David N. Gellner (ed.), Borderland Lives in Northern South Asia, Durham and London: Duke University Press, pp. 47-71.

Hausner L. Sondra and Jeevan R Sharma (2013) 'On the Way to India: Nepali Rituals of Border Crossing' in David N. Gellner (ed.), Borderland Lives in Northern South Asia, Durham and London: Duke University Press, pp. 47-71.

Ho, Enseng (2006) The Graves of Tarim: Genealogy and Mobility across the Indian Ocean, Berkeley, Los Angeles, London: University of California Press.

Ibrahim, Farhana (2011) 'Re-Making a Region: Ritual Inversions and Border Transgressions in Kutch', South Asia: Journal of South Asian Studies, n.s, 34(3), pp. 439-59.

Ingold, Tim (2011) Being Alive: Essays on Movement, Knowledge and Description, London: Routledge. 
Jackson, Michael D. (2002) The Politics of Storytelling: Violence, Transgression and Intersubjectivity, University of Copenhagen: Museum Tusculanum Press.

Jackson, Michael D. (2008) ‘Between Biography and Ethnography', Harvard Theological Review, 101 (304), pp. 377-397.

Kabir, Jahanara Ananya (2013) Partition's Post-Amnesias, New Delhi: Women Unlimited.

Magnusson, Jan (2011) 'Greater Ladakh and the Mobilization of Tradition in the Contemporary Baltistan Movement', in Anna Akasoy, Charles Burnett \& Ronit Yoeli-Tlalim (eds.), Islam and Tibet: Interactions along the Musk Routes, Farnham: Ashgate.

Marsden, Magnus (2005) Living Islam: Muslim Religious Experience in Pakistan's North-West Frontier, Cambridge: Cambridge University Press.

Pandey, Gyanendra (1992) 'In Defense of the Fragment: Writing about Hindu-Muslim Riots in India Today', Representations, 37, pp. 27-55.

Rahman, Muhammad Mahbubar; van Schendel, Willem (2003) 'I Am Not a Refugee: Rethinking Partition Migration', Modern Asian Studies, 37(3), pp. 551-584.

Sen, Geeti (ed.) (1997) Crossing Boundaries, New Delhi: Orient Longman.

Winichakul, Thongchai (1994) Siam Mapped: A History of the Geo-body of a Nation, Honolulu: University of Hawaii Press.

Zamindar Vazira Fazila-Yaccobali (2007) The Long Partition and the Making of Modern South Asia: Refugees, Boundaries, Histories, New York: Columbia University Press.

\section{NOTES}

1. This article draws upon ethnographic research carried out in Kargil district as a whole between 2008 and 2014. My interest in Kargil arose after participating in the International Association of Ladakh Studies conference held there in 2005, where I was fortunate to meet three participants from Baltistan, including Hasan Hasni. I would like to express my deepest gratitude to Bashir and Zahra Wafa, Master Sadiq Hardasi, Septe Kalim, Sadiq Ali Sadiq and other Balti interlocutors in Kargil for their time, knowledge and friendship. Critical comments and suggestions by the reviewers and editors of SAMAJ were enormously helpful in revising this piece.

2. On crossing the India-Nepal border, see Hausner and Sharma (2013). On the India-Bangladesh border, see Ghosh (2011). Despite the sealing of the Kutch-Sindh border between India and Pakistan, unlike the Kargil-Baltistan 'border', local newspapers in Kutch report illegal border crossings (see Ibrahim 2011:443).

3. See Magnusson (2011) 'Greater Ladakh and the mobilization of tradition in the contemporary Baltistan movement' in Akasoy, Burnett and Yoeli-Tlalim (eds.).

4. I draw upon Winichakul's (1994:17) conceptualization of the 'geobody'. Based on his work on Siam he argues that the geo-body of the nation is the effect of maps. A nation is discursively constructed through cartographic delineation.

5. Tarikh-e-Baltistan was written by the Dogra administrator, Hashmatullah Khan. Some local intellectuals contend that parts of it are therefore not an accurate representation of history given the Dogra oppression of Baltis.

6. See a popular forum: https://www.facebook.com/Lchangra.

7. More can be learnt about Ghulam Hasan Hasni from a documentary film on him released in 2014.

South Asia Multidisciplinary Academic Journal, 10 | 2014 
8. In 2013 Master Sadiq Hardasi published a book in Urdu on Baltis in India based on extensive research and travels, titled Balti Muhajireen Ki Mukhtasar Tareekh.

9. The trend of online chatting among Baltis kicked off after Hasni's visit to Kargil.

10. The meanings of adab draw upon an Islamicate imaginaire and typically refer to an Islamic ethos of refinement, etiquette, and civilization. Aggarwal (2004:200) too mentions the Baltis' claim to authenticity of their dialect.

11. Balti has been accorded official recognition as one of the eight regional languages through its inclusion in the Eighth Schedule of the J\&K Constitution. This is based on the pre-colonial 1941 census linguistic enumeration on the basis of population numbers. Taking into account Baltistan and Kargil there were a greater number of Balti speakers compared to Purigi, which has not been included in the Eighth Schedule. Despite the Baltis being a minority in numerical terms today, their language has constitutional status.

12. On the politicization of ethnic identity amongst the Brog-pa, see Bhan (2014).

13. Qasida (poems in praise of the Prophet, his family and the Imams), Marsiya (Muharram elegies), and Nauha (Muharram rhythmic dirges).

14. These poets have been interviewed in a recent documentary film on Hasan Hasni, whose death in 2010 was deeply mourned by Baltis in Kargil. Ali (2012) describes the centrality of poetry performances in the cultural and spiritual lives of people in Gilgit-Baltistan, where poetic expression is considered to be the 'hallmark of intellect'.

15. The category of 'State Subject' was created in 1927 under the reign of Maharaja Hari Singh to protect the rights of those residing in his kingdom. It continued to be maintained after the Dogra accession to India through its inclusion in Article 370 of the Constitution of India that grants special status to Jammu \& Kashmir. Scheduled Tribe status, which is separate from State Subject status was accorded to various ethnic groups in Ladakh in 1989.

16. I draw here on the definition of 'transmigrants' and 'exile' from Glick Schiler and Fouron (2001).

\section{ABSTRACTS}

The experience of 'cross-border dwellers' corresponds clearly neither to the category of Partition refugees nor those in exile. This article is an ethnographic case study of the Baltis in Kargil living in the India-Pakistan borderland in the province of Kashmir. It discusses the seemingly contradictory emotions of a poetics of longing for the 'other' side and a politics of belonging in India. I argue that a tension persists between the geobody of the nation-state and the affective body of the cross-border dweller. Further, subjective narrations and biography offer a subtle critique of the legitimating ideologies of nation-states on both sides of the 'border'.

\section{INDEX}

Keywords: cross-border dwellers, Kargil, Kashmir, Partition, Baltis, biographical ethnography, minorities 


\section{AUTHOR}

\section{RADHIKA GUPTA}

Research Fellow, Centre for Modern Indian Studies, Goettingen University 